\title{
Natural Products and Aquaculture Development
}

\author{
*Ugoala Emeka, ${ }^{1}$ Ndukwe George Iloegbunam, ${ }^{2}$ Ayo Rachael Gbekele-Oluwa \\ and ${ }^{3}$ Mustapha Bola \\ Fisheries Products' Development Programme, National Institute for Freshwater Fisheries Research, \\ P.M.B. 6006, New Bussa 913003, Niger State, Nigeria \\ ${ }^{I}$ Department of Chemistry, Faculty of Science, Ahmadu Bello University, Zaria \\ ${ }^{2}$ Samaru College of Agriculture, Division of Agricultural Colleges, Ahmadu Bello University, Zaria \\ ${ }^{3}$ National Institute for Pharmaceutical Research, Abuja
}

\begin{abstract}
For growth in the aquaculture sector to be sustainable in the long term, there is a critical need to make operations more efficient through effective disease control management and with optimized (and stage specific) feeds and improved feed conversion ratios. An enhanced level of integration spanning from breeding centres, to hatcheries, to nurseries and farm production is a pre-requisite for growth.Synthetic compounds use in aquaculture has created resistant bacteria, immune-suppression and destabilization of helpful bacterial population as well as environmental pollution. To replace their effects, the search for natural alternatives has begun. Through natural compound use it can be hoped to achieve the same results as in the use of synthetic compounds. The present study is a review of the use of some natural substances and of the researches made to reveal their effects on fish. Research have shown the diverse effects of these natural compounds used in fish as immune-modulators, immune-stimulants, bio-productive, antioxidants, antimicrobials, stimulants of the enzymatic equipment, stimulants of nitrogen absorption. A major advantage in the use of natural compounds is the fact that they are natural substances and do not pose any threat to fish, man or environment.
\end{abstract}

Keywords: Chemistry; Management; Pollution; Environment

\section{Introduction}

Aquaculture is growing more rapidly than all other animal food-producing sectors due to increasing demand and a concurrent decline in wild capture fisheries. Different species of plants and animals being cultured continues to increase every year with the advanced culturing/rearing techniques. Despite the various policy measures supported by numerous researches to boost fisheries production in most countries, a major characteristic of the sector is the shortfall in production target as the consumption of fisheries and products continues to increase. In order to meet the production gap, aquaculture production can be based on a short production cycle. In this process, there would be improvement in the feed conversion rate which in turn will promote weight gain and improve animal meat production capacity, and also has a bactericidal effect of wastewater aquaculture. Natural substances hold the promise of shifting the demand curve for the current demand in fisheries. Natural products can promote the growth of antimicrobial agents, increase protein assimilation and feed conversion rate, so that the animals gain weight faster without significant cumulative toxicity.

The current paper is to encourage the application of natural products to improve the immune system of fisheries, achieve greater weight gains and feed conversions and thereby increase production and consequently economic gains for producers. The idea was to develop an alternative to the excessive use of antibiotics by using natural products which are friendly to the environment to strengthen the immune system of fisheries. The lack of an immediate-release sedative (i.e., one for which no post-sedation holding or withdrawal period is required) jeopardizes fish and fisheries research and poses considerable risk to those involved in aquatic resource management and the operation of public hatcheries and commercial fish farms. The lack of an immediaterelease sedative approved is a consequence of numerous factors, including the complexities of the approval process, the substantial human and monetary resources involved, and the specialized nature of the work.

Natural active substances like alpha-pinene, alpha-terpineol, cinnamaldehyde, di-hydroeugenol, eugenol and terpinolene are included in the manufacture of feed for aquatic animals for the improvement of the feed conversion ratio and/or daily weight gain in fish, for reducing mortality by regulating the micro flora of the gut and/or by protecting the animal against infections caused by pathogenic microorganisms. Natural active substances improve risk management. Especially, a high mortality rate is a substantial risk for fish farmers.

It is generally known that mortality rate are increased by an unbalanced micro flora and/or by infections caused by pathogenic microbes. Fish diseases are common, and the likelihood of an outbreak is higher over a long growing period. There is also a risk that fish will escape due to accidents, e.g. when shifting nets, or due to bad weather causing wrecked fish pens. For other farm animals it is well known to use antibiotics 
and vaccines to prevent the development of diseases. In aquaculture, antibiotics are not so much used - at least in cold water aquaculture - due to the fact that disease spread very quickly, diseased fish do not eat much and also due to the negative impact on the environment of the wasted medicated feed. Vaccines are widely used when available but they are not developed for all diseases.

Synthetic compounds use in aquaculture has created resistant bacteria, immune-suppression and destablisation of helpful bacterial population as well as environmental pollution. Synthetic compounds with estrogenic activity disrupt normal endocrine function in wildlife populations and humans. These have created interest in the development of alternatives including the re-examination of using plant derivatives. Therefore natural immune stimulants like glucans, chitin and chitosan, vitamin $\mathrm{C}$ and $\mathrm{E}$, some polysaccharides and polyribonucleotide are being used to replace chemotherapeutic agents.

However, the use of synthetic compounds in aquaculture is not all bad. Synthetic hormones have been used to trigger difficult species (Labeo bicolor, silver sharks, Red-tail black sharks, and Clown loaches) into spawning. Also synthetic hormones are used to skew sex ratios and increase the number of males of tilapia species in order to mitigate early sexual maturation and uncontrolled reproduction.

\section{SYNTHETIC DOMINANCE}

Synthetic chemicals have being in use in fisheries since it was realized that capture fisheries are not sustainable to the growing population. A variety of chemicals are used in aquaculture for purposes such as sediment and water management, enhancement of natural aquatic productivity, transport of live organisms, feed formulation (Table 1), manipulation and enhancement of reproduction, growth promotion, health management, processing and adding value to the final product.

Table 1: Synthetic Feed Additives

\begin{tabular}{|l|c|}
\hline Compound & Activity \\
\hline Astaxanthin & artificial colouration \\
\hline Butylatedhydroxyanisole & feed preservative \\
\hline Butylatedhydroxytoluene & feed preservative \\
\hline Canthaxanthin & artificial colouration \\
\hline Ethoxyquin & feed preservative \\
\hline Vitamin C (ascorbic acid) & disease resistance \\
\hline Vitamin E & disease resistance \\
\hline
\end{tabular}

Anaesthetics and tranquilisers are used to reduce handling stress of brood stock during pituitary and male gonad extraction for milt preparation and to reduce injury and death after operation. Anaesthetics also reduce biological/metabolic activities in fish thereby relax the fish for handling and necessary operation. The most widely used anaesthetics include MS-222 (tricainemethanesulphonate), benzocaine, etomidate, metomidate, 2phenoxyethanol, quinaldine, and quinaldine sulphate.

Diseases tend to spread in aquaculture due to high stocking density and intensity of feeding in limited water areas, the proliferation of disease causing agents through the common water source between ponds, farms and the stocking of fish fry/fingerlings/brood stock from elsewhere.Bacterial diseases are responsible for heavy mortality in wild and cultured fish. The problems in the farms are usually tackled by preventing disease outbreaks or by treating the actual disease with drugs or chemicals. Antibiotics help the animals to withstand the harsh environment. The antibiotics that are usually applied to treat bacterial fish and shrimp diseases are mostly derived from human medicine, poultry science, and other branches of animal medicine. There are no antibiotics developed specifically for the purpose of treating bacterial disease of fish. Oxytetracycline or Terramycin is used widely for treatment of bacterial fish and shrimp diseases. Chloramphenicol, erythromycin, streptomycin, prefuran and neomycin are also used in the treatment of bacterial disease in shrimp and ornamental fish. Enrofloxacin (a derivative of quinolone), has recently been used as an antibacterial agent in food and ornamental fish culture. Formalin, malachite green oxalate, potassium permanganate, methylene blue, chlorine and teaseed preparations have been used to treat various diseases and to eliminate unwanted fish that act as competitors in the ponds. However, antibiotics use in aquaculture has created resistant bacteria, immunosuppression and destablisation of helpful bacterial population as well as environmental pollution.

Productive aquaculture depends heavily on availability and viability of eggs, adequate supply of fish seed or fingerlings. However, aquaculture is being hampered in Nigeria by insufficient production of fingerlings due to low survival rate, high mortality of hatchlings due to inability to easily separate egg shells and dead unhatched eggs from new hatchling quickly as well as monitoring of stress responses of the cultivable species. Inadequate supply of fish seed is mitigated through induced breeding (artificial propagation). Development of reliable spawning and fingerling production methods must be accomplished before commercial culture can be undertaken. The method routinely used to induce ovulation and spawning in many species involves injections of synthetic compounds as shown in the table below. 
Natural Products And Aquaculture Development

Table 2: Synthetic compounds used in fish seed production

\begin{tabular}{|l|c|c|}
\hline \multicolumn{1}{|c|}{ Compound } & Activity & Reference \\
\hline Trenbolone acetate & Sex inversion & Galvez et al, 1996 \\
\hline Aceto-carmine & Sex inversion & Wassermann and Afonso, 2002 \\
\hline $17-\alpha$-methyltestosterone & Sex inversion & Jo et al, 1988 \\
\hline $17-\alpha$-methyl-5-androsten-3,17-diol & Masculinisation & Varadaraj and Pandian, 1987 \\
\hline $17-\alpha$-hydroxyprogesterone & Sex inversion & Yamamoto, 1969 \\
\hline Mibolerone & Sex inversion & Porrans et al., 1988 \\
\hline Fluoxymesterone & Sex inversion & Varadaraj, 1992 1990 \\
\hline 19-norethisterone acetate & Masculinisation & Yamamoto, 1969 \\
\hline $11-$-ketotestosterone & Masculinisation & Yamamoto, 1969 \\
\hline $17-\alpha$-estradiol & Masculinisation & Yamamoto, 1969 \\
\hline Stilbestrol & Sex inversion & Yamamoto, 1969 \\
\hline Androstenedione & Sex inversion & Alok et al., 2003 \\
\hline Gonadotropin releasing hormone & Induced Spawning & Brzuska, 2002 \\
\hline Carp Pituitary Extract (CPE) & Induced Spawning & Eyo, 2002 \\
\hline Human chorionic gonadotropin & Induced Spawning & Aguigwo, 1991 \\
\hline Clomiphere citrate & ovulation & Olubiyi et al., 2005 \\
\hline Ovaprim & Induced Spawning & \\
\hline
\end{tabular}

Generally speaking, chemicals in use in aquaculture today can be grouped into three categories. The first consists of aquaculture chemicals that pose an inherently high level of hazard, and on this basis alone their use should be curtailed. This category includes chloramphenicol, organotinmolluscicides, malachite green and, potentially, some organophosphates. The second category includes chemicals that can be used safely if standard precautions are followed but pose a threat to the environment and/or human health if misused. Excessive dosage, failure to provide for adequate neutralisation or dilution prior to discharge, or lack of adequate personal protection equipment are among the factors that could make the use of an inherently acceptable chemical unsafe. The third category of chemicals includes those that may be environmentally benign under most situations but detrimental at specific sites because of the unique attributes of such sites. Proper selection of farm sites can substantially reduce the environmental impacts of aquaculture chemicals.

\section{NEED OF THE HOUR}

Part of the modernization initiative in aquaculture is ensuring the safety of products and processes by identifying, understanding, mitigating, and eliminating risks. Concern is growing over the use and potential misuse of some of these chemicals. The amount of information on chemical use in coastal aquaculture and its significance for human health assurance, environmental protection and sustainable development of the sector, has been increasing. Chemical usage is widespread in the aquaculture industry. Parasiticides, anaesthetics, spawning hormones, oxidants, disinfectants and herbicides are all routinely used. Chemicals added to the fisheries ponds, or by-products from the applied substances, that have a bioaccumulation potential, could be found as residues in aquaculture products. The issue of chemical residues by virtue of their intrinsic properties may render them of concern with regard to consumer health, including a possible increase in cancer risk in humans. Emergence of multidrug resistance among bacterial pathogens of hospital environment, domestic and industrial environment and in biofilms is reported globally. Hence, effective treatment systems using conventional antibiotics are failed. To reduce the reliance upon the convectional antioxidants, hormones, anaesthesia and tranquilizers which are unavailable, expensive and their associated health risks, natural, cheaper and non-health risk compounds must be researched.

The aquaculture sector must change as agriculture around the world, continue to become more complex. There is an important role for Researchers to help drive and disseminate key trends, activities and approaches in the sector to make resource production more efficient. There is need to maintain aquatic food's nutritional benefits for the consumer, as well as the health and welfare of the farmed fish. Algae, plankton and plants are potential alternative raw materials for fish feed production. Byproducts from fisheries and seaweed and micro-algae are some themes of research and technology transfer, and project development including supportive aquaculture development.

Natural products hold the promise of "shifting the demand curve" for synthetic chemicals for aquaculture. Since the beginning of human civilization, herbs have been used by mankind for its therapeutic value. An impressive number of modern drugs have been isolated from natural sources. Many of these isolations were based on the uses of the agents in traditional medicine. Ethno veterinary medicine is widely practised in rural areas in parts of Africa, including Nigeria. In small holder livestock systems in developing countries, ethno veterinary medicine is probably the only way to maintain and restore the health of animal species. Most rural farmers do not have access or the financial resources to synthetic drugs. These farmers rely on the ancestral indigenous knowledge in order to control various livestock diseases (Gueye, 1997). 
Conversely, because information on the use of plant species for therapeutic purpose has been passed from one generation to the next through oral tradition, this knowledge of therapeutic plants has started to decline and become obsolete through the lack of recognition by younger generations as a result of a shift in attitude and ongoing socioeconomic changes. Furthermore, the indigenous knowledge on the use of lesser-known medicinal plants is also rapidly declining. Continuous erosion in the traditional knowledge of many valuable plants for medicine in the past and the renewal interest currently, the need existed to review the valuable knowledge with the expectation of developing the medicinal plants sector. Ethno botanical knowledge is very ancient in Nigeria. It can be defined as the total natural and traditional relationship and the interaction between man and his surrounding plant wealth. The term ethno botany has often been considered synonymous with traditional medicine or with economic botany. It has been the first knowledge, which the early man acquired by sheer necessity, intuition, observation and experimentation. The scope of ethno botany is expanding at a very fast rate.

\section{OPPORTUNITIES FROM THE SUSTAINABLE USE OF NATURAL PRODUCTS}

Natural Products are rich sources of both biologically and chemically diverse organisms. These attributes can be capitalized on to provide innovative, sustainable solutions to transform these resources into both traditional and novel bio-products. Natural Products offer product development opportunities in applications ranging from food and feed ingredients, to cosmetics and cosmeceuticals, nutraceuticals and pharmaceuticals, and the production of fine chemicals, to name but a few. Natural Products offer many ways of making living aquatic resources ever more usable for people.

The world is currently facing many serious challenges. A fast-growing human population and the consequent growing demand for food, energy and water are the most serious. In addition, anthropogenic climatic change is a severe threat to mankind and requires that current greenhouse gas emissions be significantly reduced to avoid detrimental consequences for the globe. It is clear that only the use of new technologies will allow us to bridge the gap between economic growth and environmental sustainability in the long run. The markets for these bio-based products are expected to grow very strongly globally in the coming years due to four underlying, irreversible trends:

- The economics of fossil-based products are deteriorating since conventional crude oil resources are getting scarce

- The growing need for national energy security and geopolitical security

- Public pressure for environmental sustainability is increasing due to an increasing environmental awareness

- Rapid demographic growth will drive demand supported by rising economic aspirations of developing countries

These fundamental trends have triggered a vast interest in bio-based products and have placed them high on the strategic agenda of most players in a variety of industries.

\section{SUSTAINABLE AQUAFEED INGREDIENTS}

The steadily increasing population on Earth makes the sustainable production of food one of the major nutritional problems for mankind to address. Aqua feed is a diverse landscape. It represents about $60 \%$ of the operational costs of production. With rising raw material prices, it is imperative to reduce cost of feed per $\mathrm{kg}$ of fish produced. To that end, fish meal replacements are inevitability. Finding alternatives is critical to the longterm sustainable growth of aquaculture to meet projected increases in consumer demand for safe, high quality farmed aquatic foods.

Modern finfish aquaculture faces problems such as bone and skeletal deformities, cataracts, heart disorders, unspecific ulceration and various digestive disorders including intestinal colic in Atlantic cod, gastric dilatation (bloat) in rainbow trout, and intestinal tumours, at low incidence, in Atlantic salmon brood stock. Most of the mentioned problems have been related to malnutrition, feed, intensive growth and/or unfavourable environmental conditions. The disorders are often not lethal, but may imply a fish welfare problem and increase the susceptibility to secondary disorders and infectious diseases. Major changes in feed composition and feed ingredients may increase the risk for such production-related disorders in intensive fish farming. Therefore, care should be taken when choosing ingredient alternatives, both types and qualities, to prevent these nutritionrelated diseases.

Economically viable aquaculture requires the availability of cheap and nutrient rich feed ingredients. Algae, plankton and plants are potentially alternative raw materials. Alternatives are critical to the long-term sustainable growth of aquaculture to meet projected increases in consumer demand for safe, high quality farmed aquatic foods. The alternative possibilities include

- Existing commodities that have the potential for greater use in feeds include protein concentrates from grains or oilseeds and by-products from animal proteins. 
- Novel by-products from other industries include proteins re- covered from biofuel production or singlecell proteins produced from inexpensive carbon sources.

- Other sources include fish processing wastes, trimmings and/or by-catch from fishing.

- New products including meals produced from worms, insects, and marine invertebrates, and meals and oils from algae.

Below are examples of some cheap and nutrient rich feed raw materials that have been used in feed formulation.

Table 3: Natural feed ingredients

\begin{tabular}{|l|l|}
\hline Compound & \multicolumn{1}{|c|}{ Reference } \\
\hline Agro industrial waste as feedstuff & Iyayi and Aderolu, 2004 \\
\hline Feather meal as a protein source & Ayanwale, 2006 \\
\hline Cassava peel & Antai and Mbongo, 1994 \\
\hline Cassava starch as feed binder & Orire et al., 2001 \\
\hline Duckweed as feed preservative & Mbagwu and Adeniji, 1998 \\
\hline Cocoa pod husk & Fagbenro, 1988 \\
\hline Cocoa bean cake & Odunsi et al., 1999 \\
\hline Kola pod husk & Osineye et al., 2008 \\
\hline Mango kernel & Teguia, 1995 \\
\hline Aquaculture solid waste & Omitoyin et al., 2006 \\
\hline Poultry litter & Onilude, 1999 \\
\hline
\end{tabular}

There is large number of feed additives available to improve fish growth performance. Some of these additives used in feed mill are chemical products especially hormones and antibiotics which may cause unfavourable side effects. The use of antibiotic growth promoters (AGPs) as feed additives in the aquaculture industry has been criticised by government policies and consumers because of possible development of microbial resistance to these products and their potential harmful effects on human health (Baruah et al. 2008). World Health Organization encourages using of medicinal herbs and plants to substitute or minimize the use of chemicals through the global trend to go back to the nature. Attempts to use the natural materials such as medicinal plants could be widely accepted as feed additives to enhance efficiency of feed utilization and animal productive performance (Levic et al. 2008). Platel et al. (2002) found that medicinal herbs are desirable for stimulating digestion, and had the highest stimulatory influence particularly on bile secretion and pancreatic enzymes activity. In other way, olfactory feed ingredients enhance growth through their ability to act as feeding enhancers for fish to eat more feed than in normal (Adams, 2005). With the shift away from synthetic drugs, the use of medicinal herbs as an alternative for antibiotic growth- promoters in fish is becoming acceptable (Adedeji et al. 2008).

Over the past several decades, aquaculture feeds have become increasingly more efficient, environmentally-friendly and cost-effective. These impressive advances have been realized through a better understanding of the nutrient requirements of cultured species and by increased use of more sustainable feed ingredients, predominantly agricultural by-products and plant proteins. With improvements in seafood processing techniques and a growing algal bio refinery sector, there is now tremendous potential for the development of a 'next generation' of sustainable aqua feed ingredients.

The use of functional ingredients coming from fish by products in aqua feed is a good solution to bring added value to the industry. It allows manufacturers to decrease their production cost while improving feed performance. The use of good enzyme, amino-acids and protein in this respect should be investigated. Small companies producing locally can fix the raw material issue through added value and sustainability by using the $50 \%$ of total world fish production which is not used for human food.

Algal protein either as a supplement or as an alternative source is suitable as a feed supplement (Becker, 2004). Algae biomass is able to enhance the nutritional content of conventional feed preparations and hence, they positively affect the physiology of fed animals (Belay, 1996).

The use of microalgae in aquaculture could be as

- Live microalgae: indispensable for commercial rearing of larval and juvenile aquatic species

- As supplement: enhances the nutritional value of formulated feeds-via vitamins, carotenoids, phytochemicals, and highly unsaturated fatty acids

- As a potential alternative to fish meal and fish oils- valuable source of protein and energy

- Microalgae pigments: carotenoids, lutein and zeaxanthin to augment natural skin colouration in fish Microalgae have potential use as a food source in aquaculture because of its nutritional value (da Silva and Barbosa, 2008). The content of lipids, proteins (amino acids), carbohydrates and vitamins of various microalgae species is one of the main reasons for considering these organisms as feed source for aquaculture animal. Microalgae content of highly unsaturated fatty acids (HUFAs) provides the most prominent determinant of the nutritional composition of microalgae (Pratoomyot et al., 2005). High amounts of DHA, for example, are 
produced in the algae Crypthecodiniumcohnii, Thraustochytrium spp., Schizochytrium spp., Isochrysisgalbana and Crypthecodinium spp. The algae, Porphyridium cruentum and Parietochloris incise accumulate AA and several species have been suggested for the production of EPA including Nitzschia spp., Nannochloropsis spp., Navicula spp., Phaeodatylum spp. and Porphyridium spp. A slight inconvenience with using algal feedstocks directly for the production of vlcPUFAs is that in many species the accumulation of these fatty acids involves their presence in lipids other than triacylglycerides such as galactolipids.

Microalgae are utilized in aquaculture as live feeds for all growth stages of bivalve, molluscs (eg. oysters, scallops, clams and mussels), for the larval/early juvenile stages of abalone, crustaceans and some fish species, and for zooplankton used in aquaculture food chains (Singh et al., 2003). Microalgae are good feed for clams. Gulf areas, where microalgae grow abundantly, are known as being good locations for the raising of oysters. However, oyster catches fluctuate wildly in line with climate changes. Therefore, a method of using cultivated microalgae as feed for the larvae of oysters, clams, mussels and sea urchins has been drawing attention as a stable cultivation method not affected by climate changes and environmental contamination (Belay, 1996).

The high protein content of various microalgae species (Table 4) is one of the main reasons to consider them as an unconventional source of protein (Soletto et al., 2005). In addition, the amino acid pattern of almost algae compares favourably with that of other food proteins.

Table 4: The amounts of protein, lipid and carbohydrate in different types of algae (Becker, 1994; Spolaore et

\begin{tabular}{|c|c|c|c|}
\hline $\begin{array}{l}\text { SPECIES } \\
\end{array}$ & PROTEIN & LIPID & CARBOHYDRATE \\
\hline Anabaena cylindrica & 49 & 5 & 27 \\
\hline AnkistrodesmusTR-87 & - & 34 & - \\
\hline Botryococcusbraunii & - & 52 & - \\
\hline Chaetoceroscalcitrans & 34 & 16 & 6 \\
\hline Chaetocerosgracilis & 12 & 7 & 5 \\
\hline Chlamydomonasrheinhardii & 48 & 21 & 17 \\
\hline Chlorella protothecoides & - & 35 & - \\
\hline Chlorella pyrenoidosa & 57 & 2 & 26 \\
\hline Chlorella stigmatophora & 39 & - & - \\
\hline Chlorella vulgaris & 55 & 18 & 15 \\
\hline Chroomonassalina & 29 & 12 & 9 \\
\hline Crpthecodiniumcohnii & - & 20 & - \\
\hline CyclotellaDI & - & 39 & - \\
\hline Dunalielasalina & 57 & 6 & 32 \\
\hline Dunaliellabioculata & 49 & 8 & 4 \\
\hline Dunaliellatertiolecta & 54 & - & - \\
\hline Euglena gracilis & 50 & 17 & 16 \\
\hline Hantzschia & - & 66 & - \\
\hline Isochrysisgalbana & 29 & 23 & 13 \\
\hline Nannochlorisatomus & 30 & 21 & 23 \\
\hline Nannochloropsisoculata & 35 & 18 & 8 \\
\hline Nitzchiaclosterium & 26 & 13 & 10 \\
\hline NitzschiaTR-114 & - & 39 & - \\
\hline Pavlovalutheri & 29 & 12 & 9 \\
\hline Pavlovasalina & 26 & 12 & 7 \\
\hline Phaeodactylumtricornutum & 30 & 14 & 8 \\
\hline Porphyridiumcruentum & 33 & 11 & 48 \\
\hline Scenedesmusdimorphus & 13 & 28 & 37 \\
\hline Scenedesmusobliquus & 53 & 13 & 13 \\
\hline Scenedesmusquadricauda & 47 & 2 & - \\
\hline ScenedesmusTR-84 & - & 45 & - \\
\hline Schiochytrium & - & 64 & - \\
\hline Skeletonemacostatum & 25 & 10 & 5 \\
\hline Spirogyraspp & 13 & 16 & 48 \\
\hline Spirulina maxima & 66 & 7 & 15 \\
\hline Spirulinaplatensis & 55 & 6 & 11 \\
\hline Stichococcus & - & 33 & - \\
\hline Synechoccusspp & 63 & 11 & 15 \\
\hline Tetraselmischui & 31 & 17 & 12 \\
\hline Tetraselmismaculata & 52 & 3 & 15 \\
\hline Tetraselmissuecica & 41 & - & - \\
\hline Thalassiosirapseudonana & - & 26 & - \\
\hline
\end{tabular}




\section{Use of Algae to Enrich Zooplankton}

Microalgae have an important role in aquaculture as a means of enriching zooplankton for on-feeding to fish and other larvae. In addition to providing protein (essential amino acids) and energy, they provide other key nutrients such as vitamins, essential PUFAs, pigments and sterols, which are transferred through the food chain. However, often these do not provide the level of enrichment often sought for zooplankton, and commercial oil emulsions are often used (Baker and Gunther, 2004).

The high costs associated with algal production, the risks for contamination, and temporal variations in the algal food value still pose problems for any aquaculture operation depending on the mass-cultures of unicellular algae. In order to overcome or reduce the problems and limitations associated with algal cultures, various investigators have attempted to replace algae by using artificial diets either as a supplement or as the main food source. Different approaches are being applied to reduce the need for on-site algal production, including the use of preserved algae, micro-encapsulated diets, and yeast-based feeds. There is further scope to develop the sector by introducing better quality products, since it is widely acknowledged that existing concentrated microalgae products still do not match live microalgae for hatchery applications.

\section{SKIN PIGMENTATION}

Table 5: Pigments containing Plants

\begin{tabular}{|l|l|}
\hline Compound & Reference \\
\hline Marigold (Tagetes erecta) & Alma et al., 2013 \\
\hline China rose (Hibiscus rosas inensis) petals & Sinha and Asimi, 2007 \\
\hline Alfalfa, Mendicago sativa & Yanar et al., 2008 \\
\hline Paprika(Capsicum annum) & Tsushima et al., 1998 \\
\hline Yeast (Rhodotorulas anneii) & Savolainen and Gyllenberg, 1970 \\
\hline Chestnut flowers & Neamtu et al., 1976 \\
\hline Dried flowers & Torrissen et al., 1989 \\
\hline Hippophae oil (Hippophaer hamnoides) & Kamata et al., 1977 \\
\hline
\end{tabular}

Production of ornamental fish is an important business activity as well as one of the most popular hobbies in the world. It is thought that this sector can contribute to the economic development in underdeveloped countries, especially in the tropics (Yanar et al., 2008). Ornamental fish are characterized by a wide diversity of colours and colour patterns and success in the ornamental fish trade is very much dependent on the vibrant colour of the fish. The commercial value of these fish reflects this requirement; hence, ornamental fish growers are constantly exploring methods of enhancing skin colouration. This colour is derived from the deposition of carotenoids in its tissue (Simpson et al., 1981). The carotenoids are also vital nutrient for healthy growth, metabolism, and reproduction as well as colour (Miki, 1991). Since fish, like other animals, are not able to perform denovo synthesis of carotenoids (Goodwin, 1984), they have to obtain them from dietary sources. Different sources of carotenoid pigments like pure carotenoid pigments, animal source and plant source (Table 5) are included in fish diet. The use of plant source in fish feed presents a double advantage: besides being rich in carotenoid pigments, they are a direct source of nutrient like protein, lipids and vitamins.

\section{LIVE FISH TRANSPORTATION}

Stress induced by changes in environmental parameters requires homeostatic regulation that brings about behavioural and physiological alterations in aquatic animals ( $\mathrm{Li}$ and Brouwer, 2007). In aquaculture, various strategies have been applied to relief the aquatic animals from regular stressful conditions during transportation. Anaesthesia has been introduced as an applicable way to prevent stress in aquatic animals for long times.

The transport of live fish is problematic in aquaculture. The success of transporting fish depends on many factors, including the duration of transport, water parameters, the size, density and physical condition of the fish and the duration of the depuration period before fish transport (Becker et al., 2012). Anaesthetics play an important role in both fisheries research and aquaculture, being used to facilitate various handling procedures, such as weighing, sorting and collection of spawning material, tagging, or veterinary treatment (Kazuñ and Siwicki, 2001).

Table 6: Natural Anaesthetics

\begin{tabular}{|l|l|l|}
\hline Compound & organism & Reference \\
\hline Clove oil (Eugenia caryophyllata) & Largemouth bass (Micropterus salmoides) & Cooke et al., 2004 \\
\hline Eugenol & Indian Shrimp (Fenneropenaeus indicus) & Sohrab et al., 2010 \\
\hline Kigelia africana & Catfish (Clarias gariepinus) & Owolabi and Omogbai, 2007 \\
\hline
\end{tabular}

Anaesthetics act with various intensity, driving fish into general anaesthesia, resulting in loss of consciousness, inhibition of reflex activity, and reduced skeletal muscle tone (McFarland, 1960). This may reduce susceptibility 
to pathogens and infection (Matin et al., 2009). Regardless of the agent, the process of anaesthesia in fish, develops in a similar way and runs in a progressive pattern (McFarland, 1959). Overdosing an anaesthetic or retaining the fish in an anaesthetic bath for too long leads to the fading of ventilation, hypoxia, and finally, respiratory and cardiac collapse (Tytler and Hawkins, 1981).

\section{SEED PRODUCTION}

Fish seed production is a specialized farming system practiced by skilled farmers only. An increasing number of hormones and growth promoters are used to change the sex, productive viability and growth of cultured organisms. Fish seed production technique involves a series of breeding and feeding activities that can be grouped under the following successive operational stages:

- Induced spawning of eggs and milt using natural or synthetic substances

- Fertilization

- Incubation and hatching of eggs

- Nursery management

The table below contains a list of plants that may be useful in fish seed production.

Table 7: Plants used in fish seed production

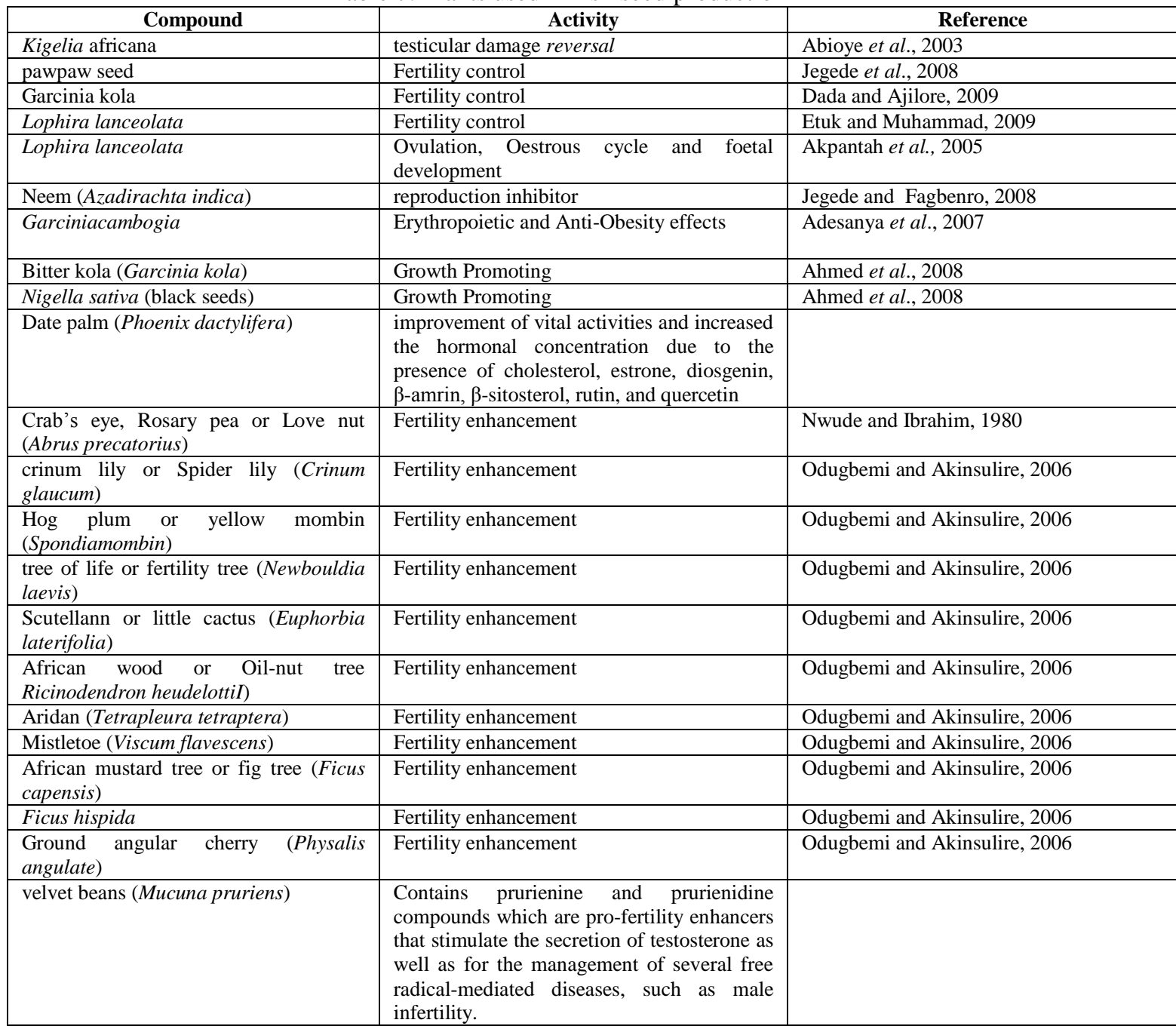

Most fisheries species are seasonal breeders. In these species, there is variation in the time of year when breeding occurs. These fisheries species therefore integrate their reproductive cycles with seasonal environmental cycles such as temperature, photoperiod and rainfall. This means that the neuro endocrine system which regulates pituitary and gonadal function can only be active during this period. Ovulation and spawning are therefore seasonal activities in most fisheries species. Reproduction in fish is regulated by external environmental factors that trigger internal mechanisms into action. The reproductive cycle can be controlled by 
either placing the fish in an appropriate environment or by changing the fish internal regulating factors with injected hormones or other substances. Sperm management by hormone treatment can become a vital tool for increasing artificial reproduction success in farms.

\section{DISEASE CONTROL (IMMUNO-STIMULANTS)}

Years of fish production and genetic selection for growth and domestication traits has pushed fish to the edge of their metabolic comfort range and increased their susceptibility to different type of stress which usually lead to amplification of oxidative stress. High oxidative stress usually reflects impairment of fish health. In particular changing fish oil or proteins to other source from vegetables. This is a challenge for producers and formulations scientists. It induces physiological stress in fish such as an inflammatory response of digestive system or inflammation of other tissues and these responses are directly related to oxidative status or oxidative stress of tissues. Both the environment and nutrition have an effect on fish, or other organisms, to generate oxidative stress on the system. Mammalian and avian research has shown that deregulation of oxidation stress and mitochondrial dysfunction is clearly related to susceptibility to infections disease. Organizations and industry have selected fish for high growth rates and these fish are known to be more susceptible to deregulation of oxidative stress.

\section{Situations creating health concerns}

- Malnutrition can be an important health issue

- Moving beyond the carrying capacity of the system can cause it to collapse, especially important in open systems where there is lots of non-controllable variation. If we continuously push intensification then we create a situation where disease occurs.

- Diluting essential feed ingredients like fish oils will be a major fish health issue

Parasites are an integral part of any aquatic environment. In aquaculture, where usually conditions are suboptimal, chances of infection are increased through raised stress levels in fish which directly affects their immune response. Poor immune response reduces the ability of fish to fight pathogens and parasites. It gives parasites the opportunity to proliferate causing serious health issues and ultimately can prove fatal to the host fish if left untreated. Synthetic chemicals offer a short term solution against parasitic problems; causing stress to the fish and increasing the chances of future infections. Many of these chemicals are not environmentally sustainable. Natural plant product promotes various activities such as anti-stress, growth promotion, appetite stimulation, immune-stimulation, aphrodisiac and antimicrobial properties.

The immune-stimulants enhance the level of duration of specific immune response, both cell-mediated and humoral, following vaccination. Immuno-stimulant supports to overcome of immunosuppressive effects of stress and of those infectious agents that damage or interface with the functioning of cells of immune system. A variety of substance have been shown to have the immune-stimulatory effects which are microbial derivatives, plants or animal extracts, vitamins, hormones and synthetic chemical but Herb extracts and animal originated product have a potential application as an immune-stimulant in fish culture, primarily because they can be easily obtained, are not expensive and act against a broad spectrum of pathogens. Most of the herbs and herb extracts (Table 8) can be given orally, which is the most convenient method of immune-stimulation.

Table 8: Natural Immuno-stimulant promoting plants

\begin{tabular}{|c|c|c|}
\hline Garlic (Allium sativum) & $\begin{array}{l}\text { improve the gain in body weight, survival rate and resistance } \\
\text { against challenge infection }\end{array}$ & Salah et al., 2008 \\
\hline Purple coneflowers (Echinacea) & $\begin{array}{l}\text { Anti-tumour and immune-stimulator effects, especially in the } \\
\text { case of non-specific immune system. }\end{array}$ & Salah et al., 2008 \\
\hline Ginger, (Zingiber officinale) & $\begin{array}{l}\text { Control infection, proliferation in the numbers of neutrophils, } \\
\text { macrophages and lymphocytes and enhanced phagocytic and } \\
\text { lysozyme activity. }\end{array}$ & Nya and Austin, 2009 \\
\hline Tulsi (Ocimum sanctum) & Immune-stimulant & Jayathirtha and Mishra, 2004 \\
\hline Amla (Phyllanthus emblica) & $\begin{array}{l}\text { antioxidant activity, anti-fungal activity, antimicrobial activity } \\
\text { and anti-inflammatory activity }\end{array}$ & Jayathirtha and Mishra, 2004 \\
\hline Neem(Azadirachta indica) & anti-tumour and antimicrobial activities & Rao and Chakrabarti, 2005 \\
\hline $\begin{array}{l}\text { Purple Fruited Pea Eggplant } \\
\text { (Solanum trilobatum) }\end{array}$ & $\begin{array}{l}\text { antibiotic, antibacterial and anticancer activity, nonspecific } \\
\text { immune mechanisms and disease resistance }\end{array}$ & Nya and Austin, 2009 \\
\hline Green tea (Camellia sinensis) & antioxidant, anti-angiogenesis, and anti-proliferative & Yoshida et al.,1993 \\
\hline Aloe vera & $\begin{array}{l}\text { enhance some of specific and non-specific immune responses } \\
\text { by increasing lysozyme activity, serum bactericidal power and } \\
\text { the total protein and IgM levels }\end{array}$ & Alishahi et al., 2010 \\
\hline $\begin{array}{ccc}\begin{array}{c}\text { Bermuda } \\
\text { dactylon })\end{array} & \text { grass } \quad \text { (Cynodon } \\
\end{array}$ & effective in preventing infection & Balasubramanian et al., 2008 \\
\hline $\begin{array}{ll}\text { Prickly } & \text { Chaff } \\
\text { Flower(Achyranthesaspera) } & \\
\end{array}$ & $\begin{array}{l}\text { enhances both specific and non-specific immunity in fish by } \\
\text { increasing serum globulin level, RNA/DNA ratio of the }\end{array}$ & Sahoo and Mukherjee, 1999 \\
\hline
\end{tabular}




\begin{tabular}{|l|l|l|}
\hline & $\begin{array}{l}\text { spleen, higher serum antibody levels and higher serum anti- } \\
\text { proteases }\end{array}$ & \\
\hline $\begin{array}{l}\text { Night-flowering Jyctanthesarbortristis) } \\
\text { Nysmine }\end{array}$ & $\begin{array}{l}\text { Possesses hepato-protective, anti-leishmanial, antiviral and } \\
\text { antifungal activities. Nyctanthesarbortristis enhances serum } \\
\text { lysozyme, alternate complement activities, cellular reactive } \\
\text { oxygen species, reactive nitrogen intermediate and MPO } \\
\text { production. }\end{array}$ & \\
\hline Chitin and chitosan & non-specific immune-stimulators & Shahjahan et al., 2004 \\
\hline Fermented products of chicken egg & dose dependent immune-modulatory effects & Wang and Chen, 2005 \\
\hline
\end{tabular}

\section{WASTEWATER TREATMENT}

There are two main areas where seaweeds have the potential for use in wastewater treatment. The first is the treatment of sewage and some agricultural wastes to reduce the total nitrogen- and phosphorus-containing compounds before release of these treated waters into fish culture systems. The second is the removal of toxic metals from industrial wastewater.

Treatment of wastewater to reduce nitrogen- and phosphorus-containing compounds

Eutrophication is the enrichment of waters with nutrients such as minerals and nitrogen- and phosphoruscontaining materials. This frequently leads to unwanted and excessive growth of aquatic or marine plants; blooms of blue-green algae are an example, unfortunately becoming more common. Eutrophication can occur naturally, but it can be accelerated by allowing water, rich in dissolved fertilizers, to seep into nearby lakes and streams, or by the introduction of sewage effluent into rivers and coastal waters. Seaweeds can be used to reduce the nitrogen and phosphorus content of effluents from sewage treatments. Many types of seaweed have a preference to take up ammonium as the form of nitrogen for their growth and ammonium is the prevalent form of nitrogen in most domestic and agricultural wastewater. Another important feature of many types of seaweed is their ability to take up more phosphorus than they require for maximum growth. It would be preferable to use seaweeds that have some commercial value, but these do not necessarily have the ability to withstand the conditions encountered in the processing of the wastewater. There is a need for the seaweed to be able to tolerate a wide variation in salinity because of the dilution of salinity by the sewage or wastewater. Intertidal and estuarine species are the most tolerant, especially green seaweeds such as species of Enteromorpha and Monostroma. Of the red and brown seaweeds that are of interest because of their commercial value, tropical or subtropical forms have been successfully used, while cold-temperate species are usually too sensitive to changing seasons and may fail to grow (and remove nutrients) in the winter months. While many investigations have demonstrated the suitability of seaweeds for wastewater treatments, their use on a large scale is yet to be implemented, although this may change with the increasing realization of the need to protect marine environments.

\section{Removal of toxic metals from industrial wastewater}

The accumulation of heavy metals (such as copper, nickel, lead, zinc and cadmium) by seaweeds became apparent when those seaweeds used as human foods were first analyzed. The heavy metal content, especially of the large brown seaweeds, varied according to their geographic source and sometimes to their proximity to industrial waste outlets. From these studies came the idea of using seaweeds as biological indicators of heavy metal pollution, either from natural sources or from activities such as mining or disposal of industrial wastes. This has been successfully implemented using brown seaweeds such as Sargassum, Laminaria and Ecklonia, and the green seaweeds Ulva and Enteromorpha.

Milled, dried species of the brown seaweeds Ecklonia, Macrocystis and Laminaria were able to adsorb copper, zinc and cadmium ions from solution. In another laboratory-scale trial, Ecklonia maxima, Lessoniaflavicans and Durvillaeapotatorum adsorbed copper, nickel, lead, zinc and cadmium ions, though to varying extents depending on the seaweed type and metal ion concentration. After the extraction of alginate from brown seaweeds there is an insoluble waste product, mostly cellulose, and the adsorbing properties of this have been tested and found to equal some of the brown seaweeds. Using such a waste material is obviously more attractive than use of the dried seaweed itself. Another waste product, from the production of Kelpak, the liquid fertilizer previously mentioned, has also been tested and found to adsorb copper, cadmium and zinc just as effectively as the seaweed from which it is derived. So there is the potential to use either seaweed or residues remaining from seaweed extraction. It is a matter of whether this is the most economical way to do so, depending on their availability and cost at the source of the waste

\section{Use of biochar to manage water quality}

Biochar may offer benefits in reducing diffuse pollution originating from agriculture through deployment in soils from which polluting elements arise. It may also be possible to utilize its sorptive capacity to remove contamination in the water treatment process. However, whilst biochar may loosely hold nutrient 
elements in a plant-available form, the by-product of water treatment could also be contamination by toxic organic compounds in wastewater. This could confound use of the post-treatment biochar product on land; the economic and overall carbon and environmental gain to be achieved from centralized versus diffuse deployment for management of water quality have yet to be assessed. The precedent for a centralized approach is the current use of activated carbon for the removal of chlorine and organic chemicals such as phenols, polychlorinated biphenyls, trihalomethanes, pesticides and halogenated hydrocarbons, heavy metals, and organic contaminants. It is not clear whether the higher surface area and sorptive capacity resulting from activation of biochar from agricultural crop wastes results in significant differences compared to biochar.

\section{Conclusion}

Plant extracts and animal originated product have a potential application in fish culture, primarily because they can be easily obtained, are not expensive and act against a broad spectrum of pathogens. The use of plant products in fish culture systems may also be of environmental value because of their biodegradability. Due to their beneficiary attributes, we conclude that herbal extracts and animal originated product can be used in fish culture as alternatives to vaccines, antibiotics or chemotherapeutic agents.

\section{References}

[1]. Abioye, A. I. R; Duru, F.I.O.; Noronha, C.C. and Okanlawon, A. O. (2003). Aqueous extract of the bark of Kigelia Africana reverses early testicular damage induced by methanol extract of Carica papaye. Nigerian Journal of Health and Biomedical Science 2(2). 81-87.

[2]. Adedeji, O. S.; Farimi, G. O.; Ameen, S. A. and, Olayemi, J. B. (2006). Effects of bitter kola (Garcinia kola) as growth promoter in Broiler Chicks from day old to four weeks old. Journal of Animal and Veterinary Advances, 5(3): $191-193$.

[3]. Adesanya, O. A.; Oluyemi, K. A.; Omotuyi, I. O.; Saalu, C. L. and Josiah, S. J. (2007). Erythropoietic and Anti-Obesity effects of Garcinia cambogia (Bitter Kola) in Wistar rats. Biotechnology Applications in Biochemistry. 46: 69 - 72

[4]. Aguigwo, J. N. (1991). Ovulation in Clariasalb punctatus using clomiphere citrate. Journal of Aquatic Science, 7:1-6

[5]. Ahmed, J.M.;Farouq, A.A.;Yerima, M.B. and Bello, A.M. (2005) Acute toxicity of water extract of the bark of African locust bean on tilapia (Oreochromis niloticus). $41^{\text {st }}$ Annual Conference of Science Association of Nigeria, April 25-29

[6]. Akpantah, A. O.; Oremosu, A. A.; Noronhna, C. C.; Ekanem, J. B. And Okanlawon, A. O. (2005). Effect of Garcinia kola seed extracts on ovulation, Oestrouscycle and foetal development in cyclic female Sprague dawleyr at. Nigerian Journal of Physiological Science 20 (1-2): $58-62$.

[7]. Alishahi,M.; Ranjbar,M. M.;Ghorbanpour, M.; Mesbah, M. and RaziJalali, M. (2010). International Journal of veterinary research, 4:189-195.

[8]. Alma A. del Villar-Martínez, Juan C. Orbe-Rogel, Pablo E. Vanegas-Espinoza, Adrián G. Quintero-Gutiérrez, Maurilio Lara-Flores (2013). Research Journal of Fisheries and Hydrobiology, 8(2): 31-37

[9]. Alok, D.; Krishnam, T.; Talmar, C. P. and Garg, L. C. (2003). Induced spawning of catfish Heteropnuestes fossillis using gonadotropin releasing hormone, Aquaculture 115:159-167

[10]. Antai, S. P and Mbongo, P. M. (1994). Utilisation of cassava peels as substrate for crude protein formation. In plant food for Human Nutrition, 46:345

[11]. Ayanwale, B. A. (2006). Evaluation of feather meal as a protein source in rabbit diet. Department of Animal production, Federal University of Technology, Minna Nigeria

[12]. Balasubramanian, G.;Sarathi,M.;Venkatesan, C.; Thomas, A.S. and Hameed, S(2008). Aquaculture, 279, 2-5

[13]. Baker, R. and Gunther, C.(2004). The role of carotenoids in consumer choice and the likely benefits from their inclusion into products for human consumption. Trends in Food Science and Technology, 15: 484-488.

[14]. Becker, E. W. (1994). Microalgae: biotechnology and microbiology. Cambridge University Press.

[15]. Becker,E. W.(2004). Microalgae in human and animal nutrition, p. 312-351. In Richmond, A. (ed.), Handbook of microalgae culture. Blackwell, Oxford.

[16]. Belay, A. (1996). Current knowledge on potential health benefits of Spirulina platensis. Journal of Applied Phycology, 5: 235-240.

[17]. Benkeblia N. (2003). Antimicrobial activity of essential oil extracts of various onions (Allium cepa) and garlic (Allium sativum). Swiss Society of Food Science and Technology. Published by Elsevier Science Ltd.

[18]. Brzuska, E. (2002). Spawning of African catfish, Clarias gariepinus: stimulation of ovulation using carp pituitary and Ovopel. Journal of Applied Aquaculture, 12:13-22

[19]. Cooke, S.J.; Cory, D.; Suski, K.G.; Ostrand, Tufts B.L. and Wahl, D.H. (2004). Behavioral and physiological assessment of low concentrations of clove oil anaesthetic for handling and transporting largemouth bass (Micropterus salmoides). Aquaculture, 239: 509-529.

[20]. Da Silva, R. L. and Barbosa, J. M. (2008). Seaweed meal as a protein source for the white shrimp Litopenaeus vannamei. Journal of Applied Phycology 1-5.

[21]. Dada, A. A. And Ajilore, V. O. (2009). Use of ethanol extracts of Garcinia kola as fertility enhancer in female catfish Clarias gariepinus brood stock. International Journal of Fisheries and Aquaculture (1): 005-010.

[22]. Ekanem, S.B. and Okoronkwo, T.E. (2003). Pawpaw seed as fertility control agent on male Nile tilapia. NAGA ICLARM Quarterly 26 (2): 8-10.

[23]. Etuk, E. U. and Muhammad, A. A. (2009). Fertility enhancing effects of aqueous stem bark extract of Lophiral anceolatain male Sparguedawley rats International Journal of Plant Physiology and Biochemistry Vol. 1(1) pp. 001-004

[24]. Eyo, J. E. (2002). The influence of HCG on female Clarias gariepinus ovarian development, 2:35-46

[25]. Fagbenro, A.B (1988). Preliminary studies on the utilization of cocoa pod husk in fish production in southwest Nigeria. Biowaste $25: 233$

[26]. Galvez, J. I.; Morrison, J. R. and Phelps R. P. (1996). Efficacy of Trenbolone acetate in sex inversion of the blue tilapia Oreochromis aureus. Journal of World Aquaculture Society 27:483-486

[27]. Goodwin, T.W. (1984). The Biochemistry of carotenoids. Volume II. Animals. Chapman and Hall, New York, 224 pp.

[28]. Iyayi, E.A and Aderolu, Z.A. (2004). Enhancement of feeding value of some agro-industrial by-products for laying hens after their solid state fermentation with Trichoderma virile. African journal of biotechnology 3(3):182-185 
[29]. Jayathirtha, M. G. and Mishra, S. H.(2004).Phytomedicine, 11:361-365.

[30]. Jo, Jay-yoon; Smitherman, R. O. and Behrends, L. L. (1988). Effects of dietary $17-\alpha$-methyltestosterone on sex reversal and growth of Oreochromis aureus. In R.S.V Pullin, Bhukaswan, T; Tonguthai, K and Maclean, J. L. (eds). The second international symposium on tilapia in aquaculture. ICLARM Conference proceedings, Manila, Philippines

[31]. Jegede, T. and Fagbenro, O.A. (2008). Dietary neem (Azadirachta indica) leaf meal as reproduction inhibitor in redbelly tilapia, Tilapia zillii (Gervais 1848). Proceedings of the 8th International Symposium on Tilapia in Aquaculture (ISTA 8), Cairo, Egypt.

[32]. Kamata, T.;Neamtu, G.G. and Simpson, K.L. (1977). The pigmentation of rainbow trout (Salmo gairdneri) with Hippohaerhamnoidesoil. Reviews Roumaine Biochine, 13: 25-30.

[33]. Kazuñ K., Siwicki A.K. (2001). Propiscin: a safe new anaesthetic for fish. Archives of Polish Fisheries9:183.190.

[34]. Logambal, S. M. and Michael, R. D. (2000).Indian Journal of Experimental Biology, 38:1092-1096

[35]. Li, T. and Brouwer, M. (2007). Hypoxia-inducible factor,gsHIF, of the grass shrimp Palaemonetes pugio:Molecular characterization and response to hypoxia. Comprehensive Biochemistry and Physiology 147 (B): 11-19.

[36]. Matin, S.M.A.;Hossain, M.A. and Hashim, M.A. (2009). Clove oil anaesthesia in singhi (Heteropneuses fossilis) and lata (Channa punctatus) fish. The Bangladesh Veterinarian, 26: 68-73.

[37]. Mbagwu, I. G. and Adeniji, H. A. (1998). The nutritional content of duckweed (Lemma paucicostata) in the Kainji Lake area. Aquatic Botany 29:351-366

[38]. McFarland W. N. (1960). The use of anaesthetics for the handling and the transport of fishes. California Fish and Game 46: 407.431.

[39]. McFarland W. W. (1959). A study of the effects of anaesthetics on the behaviour and physiology of fishes. Publications of the Institute of Marine Science (Texas) 6:23.55.

[40]. Miki, W. (1991). Biological functions and activities of animal carotenoids. Pure Applied Chemistry, 63: 141-146.

[41]. Natrah, F.;Yosoff, F. M.; Shariff, M.; Abas, F. and Mariana, N. S. (2007). Screening of Malaysian indigenous microalgae for antioxidant properties and nutritional value. Journal of Applied Phycology, in press.

[42]. Neamtu G.G.; Weaver, C.M; Wolke, R.E. and Simpson, K.L. (1976). The pigmentation of rainbow trout with extracts of floral parts form Aesculus. Review Roumaine de Biochime, 13: 25-30.

[43]. Nwude, N. and Ibrahim, M. A. (1980). Plants used in traditional veterinary medical practice in Nigeria. Journal of Veterinary Pharmacology and Therapeutics, 3:261-273

[44]. Nya, E. J. and Austin, B. (2009). Use of dietary ginger, Zingiber officinale Roscoe, as an immunostimulant to control Aeromonas hydrophila infections in rainbow trout, Oncorhynchus mykiss (Walbaum);Journal of Fish Diseases, 32:971-977.

[45]. Odugbemi, T. and Akinsulire, O. (2006). Medicinal plants by family and species names. Outlines and pictures of medicinal plants from Nigeria, Edited by Odugbemi, T., pp. 73-161

[46]. OdunsiA.A.;Sobamiwa, O and Longe, O.G (1999). Comparative utilization of alkali treated and untreated cocoa bean cake in diets of egg-type chickens. Tropical Animal Science 2(1):63-68

[47]. Olubiyi, O. A.; Ayinla, O. A. and Adeyemo, A. A. (2005). The effect of various doses of ovaprim on reproductive performance of the African catfish, Clarias gariepinus. African journal of Applied Zoology and Environmental Biology, 7:101-105

[48]. Omitoyin, B.O.; Fagade, O.E.; Ogunjobi, A. A.;Ogbona, J; Ajani, E.K. and Oyelade, A. A (2008). Preliminary investigation on the conversion of aquaculture solid waste into single cell protein from recirculatory slog for fish feed. Nigerian journal of Fisheries 5(2):107-122

[49]. Onilude, A. A (1999). Fermented poultry litter band fungal enzymes supplementation of high fibre broiler diets. Inter science journal 43(1):54-60

[50]. Orire, A.M.; Sadiku, S.O.E. and Tiamiyu, L.O. (2001): Suitability of cassava (Manihot esculenta) starch as feed binder. Science forum: Journal of pure and Applied Science 4(1) 61-65.

[51]. Osineye, O. M; Ashade, O. O.; Oshisanya, K. I.; Adegbile, O. M and Ariyo, A. A (2008). Kola pod Husk as a total substitute for maize in the diet of tilapia. Nigerian journal of Fisheries 5(2):123-129

[52]. Owolabi, O.J. and Omogbai, E.K.I. (2007). Analgesic and anti-inflammatory activities of the ethanolic stem bark extract of Kigelia africana. African Journal of Biotechnology 6 (5):582-585.

[53]. Pratoomyot, J.; Srivilas, P. and Noiraksar, T. (2005). Fatty acids composition of 10 microalgal species. Journal of Science and Technology 27:1179-87.

[54]. Phelps R. P.; Cole, W. and Katz, T. (1992). Effect of Fluoxymesterone on sex ratio and growth of Nile tilapia, Oreochromis niloticus. Aquaculture and Fisheries Management 23:405-410

[55]. Rao, V. and Chakrabarti, Y. R. (2005).Fish and Shellfish Immunology, 18:327-334.

[56]. Sahoo, P. K. and Mukherjee, S. C. (1999). Journal of Aquaculture in the Tropics, 14 (3):209-215.

[57]. Salah, M. A.; Mohamed F. M. and George, J. (2008). Echinacea as immune-stimulatory agent in Nile tilapia (Oreochromis niloticus) via earthen ponds experiment; 8th International Symposium on Tilapia in Aquaculture

[58]. Savolainen J.R.T. and Gyllenberg, H.G. (1970). Feeding of rainbow trout with Rhodotorula sanneii preparations.II. Amounts and qualities of carotenoids. Lebensm-Wiss Technology, 3: 18-20.

[59]. Shahjahan,M.; Sabitha, K. E.; Jainu, M. and Shyamala, C. S. (2004). Devi, Indian Journal of Medical Research, 120:194-198.

[60]. Simpson, K. L.; Katayama, T. and Chichester, C. O. (1981).Carotenoids in fish fed. In: J. C. Bauernfeind (Ed.). Carotenoids as Colourant and Vitamin A Precursors. Academic Press, New York pp. 463-538.

[61]. Singh, S.; Kate, B. N. and Banerjee, U. C. (2003). Bioactive compounds from Cyanobacteria and Microalgae: an overview. Critical Reviews in Biotechnology, 25:73-95.

[62]. Sinha, A. and Asimi, O. A. (2007). China rose (Hibiscus rosasinensis) petals: a potent natural carotenoid source for goldfish (Carassius auratus L.). Aquaculture Research, 38: 1123-1128.

[63]. Sohrab Akbari1, Mohammad J. Khoshnod, Hamid Rajaian, Mohammad Afsharnasab (2010). The Use of Eugenol as an Anesthetic in Transportation of with Indian Shrimp (Fenneropenaeus indicus) Post Larvae. Turkish Journal of Fisheries and Aquatic Sciences 10: $423-429$

[64]. Spolaore, P.; Joannis-Cassan, C.; Duran, E. and Isambert, A. (2006). Commercial applications of microalgae. Journal of Bioscience and Bioengineering 101: 87-96

[65]. Teguia, A. (1995). Substituting mango kernels for maize in broiler starter diets. Animal Feed Science and Technology 56:155-158

[66]. Torrans, L.; Meriwether, F.; Lowell, B.; Wyatt, B and Gwinup, P. D. (1988). Sex reversal of Oreochromis aureus by immersion in Mibolerone, a synthetic steroid. Journal of World Aquaculture Society 19(3):97-102

[67]. Torrissen O.J.; Hardy, R.W. and Shearer, K.D. (1989). Pigmentation of salmonids: carotenoid deposition and metabolism. Reviews in Aquatic Science, 1: 209-225. 
[68]. Tsushima, M.; Hidetada, N. and Takao, M. (1998). The accumulation of pigments from paprika in the integument of goldfish, Carassius auratus. Fisheries Science, 64: 656-657.

[69]. Tytler, P. and Hawkins, A.D.(1981). Vivisection, anaesthetics and minor surgery. Pp: 247.278. In: Hawkins A.D.(ed.) Aquarium systems. Academic Press, New York ,NY, USA.

[70]. Varadaraj, K. (1990). Production of monosex male Oreochromis mossambicus by administrating 19-norethisterone acetate. Aquaculture and Fisheries Management 21:133

[71]. Varadaraj, K and Pandian, T. J (1987). Masculinisation of Oreochromis mossambicus by administration of 17- $\alpha$-methyl-5androstendiol through rearing water. Current Science $\quad 56: 412$

[72]. Wassermann, G. J. and Afonso, L. O. B. (2002). Validation of the Aceto-carmine technique for evaluating phenotypic sex in Nile tilapia fry. Cienc. Rural 32 no.1, Santa Maria

[73]. Wang, S. H. and Chen,J. C. (2005). Fish and Shellfish Immunology, 19:191-204

[74]. Yanar, M.; Erçen, Z.; Hunt, A.Ö. and Büyükçapar, H.M. (2008). The use of alfafa, Mendicago sativa as natural carotenoid source in diets of goldfish, Carassius auratus. Aquaculture, 284: 196-200.

[75]. Yamamoto, (1969). Use of Steroids in fish sex determination: in Beveridge and J.M.C Andrew 2000 tilapia, Biology and Exploitation 244p

[76]. Zheng, Z.L.; Tan, J. Y.W.; Liu, H.Y.; Zhou, X.H.; Xiang, X. and Wang, K.Y. (2009).Evaluation of oregano essential oil (Origanum heracleoticum L.) on growth, antioxidant effect and resistance against Aeromonas hydrophilain channel catfish (Ictalurus punctatus); Aquaculture 292:214 